\title{
DIGNITY PROMOTED OR VIOLATED: HOW DOES THE DEAF PERSON INCLUDED PERCEIVE IT?
}

\section{ROSANA JUÇARA DE SOUZA REIS}

Master's Degree in Business Management from the Business Administration Program,

DeVry Brasil - Faculdade Boa Viagem (FBV).

Professor at the Department of Administration,

DeVry Brasil - Faculdade em Imperatriz (Facimp).

Av. Prudente de Morais, s/n, Parque Sanharol, Imperatriz - MA - Brasil - CEP 65900-000

E-mail: rosanareis22@gmail.com

\section{MICHEL MOTT MACHADO}

$\mathrm{PhD}$ in Business Administration from the Business Administration Program,

Universidade Presbiteriana Mackenzie (UPM).

Professor at the Department of Business Administration,

Universidade de Mogi das Cruzes (UMC).

Av. Dr. Cândido Xavier de Almeida e Souza, 200, Centro Cívico,

Mogi das Cruzes - SP - Brasil - CEP 08780-911

E-mail: michel.machado@umc.br

\section{HAJNALKA HALÁSZ GATI}

$\mathrm{PhD}$ in Education from the Department of Education,

Federal University of Pernambuco (UFPE).

Full Professor at the Department of Administration,

Faculdade Boa Viagem and DeVry Brasil.

Rua Jean Emile Favre, Imbiribeira, Recife - PE - Brasil - CEP 51200-060

E-mail: hajgati11@gmail.com

\section{JAMES ANTHONY FALK}

$\mathrm{PhD}$ in Public Administration from the Political Science Department,

University of Georgia (UGA).

Professor at the Department of Administration,

Faculdade Boa Viagem and DeVry Brasil.

Rua Jean Emile Favre, 422, Imbiribeira, Recife - PE - Brasil - CEP 51200-060

E-mail: thefalks@terra.com.br 


\section{SUMMARY}

Purpose: To understand how dignity is perceived by deaf people inserted into organizations, from their interactions with colleagues, bosses and the organization itself.

Originality/gap/relevance/implications: In the field of studies on organizational dignity, the phenomenon is being studied under several aspects. However, no research was found addressing the possible relationship between dignity and inclusion in organizations, focusing specifically on deaf people.

Key methodological aspects: This is a qualitative study carried out by means of interviews with 13 oral and non-oral deaf persons with work experience in organizations in the Metropolitan Region of Recife-PE, Brazil.

Summary of key results: Most deaf people felt socially isolated, not being considered neither by Human Resource practices, nor the target of opportunities in organizations. Oral language proved to be the main difficulty for communication within the organization, although the breakage of this barrier through the maintenance of an interpreter is supported by law.

Key considerations/conclusions: The predominant view of dignity by the deaf was based on the elements of valorization/respect/equality. It is inferred that the more intense the experience with elements that violate dignity, the less the feeling of inclusion or the greater the feeling of non-acceptance and the consequent greater risk of social isolation of the deaf. It is believed that, among other aspects, an organizational position aimed at reciprocal recognition and mutual cultural enrichment will contribute to the improvement of the quality of relationships between the deaf and the hearing.

\section{KEYWORDS}

Dignity. Deaf people. Organizational. Inclusion. Social isolation. 


\section{INTRODUCTION}

Dignity is a recurrent issue that pervades the history of humanity. There are studies on dignity in various fields of knowledge, such as philosophy (Kant, 2005), health (Hall et al., 2017; Jacobson, 2009), law (Lima, 2012), among others.

In the area of administration, studies are focused on the dignity of the worker (Teixeira et al., 2014), but do not contemplate the Person with Disability (PwD), specifically the deaf person. Other studies focus on the PwD, but focused on the issue of diversity and inclusion (Stolarczyk, 2016; Torres \& Perez-Nebra, 2014). No research was found that addressed the possible relationship between dignity and inclusion in organizations. Therefore, the present study is considered pertinent and timely, and its central objective was to understand the vision of dignity from the point of view of the deaf inserted within an organization.

In Brazil, the federal government instituted laws to guarantee basic rights for these people, which became part of the lives of the PwD. This new legal condition was endorsed, among others, by Law No. 8,213/91 (Law of Cotas), which established percentages of employment opportunities for PwD, enabling their insertion into the labor market, which increased the challenges to diversity management and inclusion in organizations.

In the country, the number of deaf people has almost doubled between 2000 and 2010 (around 9,7 million). Of these, 3 million are between 20 and 54 years old, representing a slice of the deaf population that is economically active (IBGE, 2010).

One of the concerns of this study was to investigate whether organizations have developed policies that promote the effective inclusion (Torres \& Pérez-Nebra, 2014) of the deaf through a decent action of the organization in relation to these people (Teixeira, 2008; Teixeira et al., 2014). It is based on the elements of promotion and violation of the dignity of Jacobson (2009), in the interaction with colleagues, bosses and organization.

Jacobson (2009) states that dignity is the essence of the human being. It is a universal value, the quality that the individual possesses. At the same time, it is believed that the idea of dignity in relationships has fertile ground in studies focused on the behavior of individuals and on group interactions in organizations. It was on this path that this study was directed.

In view of the above, this paper is based on the following research question: How is dignity, in the organizational context, perceived by the deaf people inserted into organizations located in the Metropolitan Region of Recife-PE? 


\section{THEORETICAL REFRENCES}

\subsection{Conceptions of dignity and its study in the organizational scope}

In ancient Greek, dignity was neither considered a full human characteristic, nor an absolute or sacred value. Dignity was an attribute only of free men (Riley, 2010).

The Judeo-Christian view was fundamental to the process of disseminating the concept of dignity as inherent to man, as something intrinsic to the human being, a tradition that influenced the conception that man would be inherently good, since he is considered the image of God (Koehn \& Leung, 2008). Dignity would thus be a consequence of human nature, providing an essentialist view of human dignity (Idem). Moreover, a relational characteristic in dignity is recognized, so that it could not be lost, because it is intrinsically human, but it could be violated (ibid.).

Thomas Aquinas affirmed the universality of human dignity influenced by the vision of dignity coming from God, as well as by man's rationality (Nicolas, 2003), which would give him a dignity due to his condition of being human (Aquino, 2008). Thus, dignity would not derive from the imago Dei, not representing a rupture with the Divine, however, since the nature of Divine dignity would exceed any other form of dignity (Aquinas, 2011). In the Middle Ages, dignity would also be associated with social groups/ individuals, depending on social status. Dignity was conceived as a personal distinction (Gosdal, 2007).

The Renaissance period challenged the understanding of dignity by integrating a positive view of man as a being endowed with reason granted by the Creator, possessing a dignity of his own and capable of making personal moral choices. This dignity would be not only inherent to man himself, but also derived from what his action produces (Riley, 2010). Also in this period, Giovanni Pico della Mirandola (1463-1494) affirmed that the dignity of man was associated with his freedom granted by God (Mirandola, 1988).

For Immanuel Kant, considered a classic thinker for the development of the modern concept of dignity, the essentiality of the dignity of man is found in his humanity, that is, it is an intrinsic value of human beings (Abbagnano, 1998; Riley, 2010). In the "Rationale of the Metaphysics of Customs", the German philosopher attested to the Enlightenment influence on his conception of dignity, which brought with it the dimension of moral value emanating from humanity itself (Kant, 2005). 
The Kantian view of human dignity, at least in the Western world, has shaped the modern understanding of the term. It has provided a basis for some legal approaches (Riley, 2010), as the very understanding of human rights in a Universalist perspective (Sarlet, 2008).

Dignity, from a sociopolitical approach, must be something to be preserved and guaranteed by universal law, as well as by the clash of social and political forces within the state (Medeiros, 2013). It emphasizes the conception of dignity produced through civil society and the democratic process, based on communicative action and popular participation (Habermas, 2010).

A view that seeks to go beyond the sociopolitical conception is one that denounces the colonization of "human rights" by means of a modern rationality. This approach brings to the surface the need to decolonize the concepts of humanity and of humans (Mignolo, 2013), and, in the same way, respect "the differences of alternative concepts of human dignity" (Santos \& Nunes, 2005, p. 25). Medeiros (2013, p. 28) defends "the need to establish an intercultural dialogue on human dignity and, once based on it, create a cross-cultural understanding of human rights", which opens a possibility to the approach of a post-modern criticism of dignity (Machado \& Teixeira, 2016).

In the field of studies on organizational dignity, research has contemplated issues directed to various dimensions of work, for example: work dignity/worker (Hodson \& Roscino, 2004); wages and decent living (Rayman \& Reynolds, 2001); gender and work dignity (Crowley, 2013); meaning of work, alienating work and its reflections on the life of the worker and at work (Hodson \& Roscigno, 2004); market demands, competition, productivity, and dignity (Shahinpoor \& Matt, 2006); lack of respect at work (Sayer, 2007).

Teixeira (2008), noting that the worker remained isolated in the relationship with the organization and other social segments, critically observed the concept of organizational dignity (OD), while Margolis (1997), proposed the construction of an organizational action based on trust and reciprocity as presuppositions for the understanding of a worthy organization. Teixeira et al. (2014) analyzed OD practices perceived by workers in the relationship between the organization and its stakeholders.

Recently, another theory of OD was proposed, in which it is understood that OD is linked to shared practices and values within the organization, which could also be experienced by stakeholders in their interaction with the organization (Teixeira \& Bilsky, 2015). A further step was the identification of four facets of the OD construct: cultural elements; ethical guidance; focus (more staff-oriented or social); and classifying OD, from top to bottom, as moral, legal or pragmatic (Teixeira, 2016). 
There is also the understanding that dignity should be presented in two ways, human dignity and social dignity (Jacobson, 2007; 2009). The first would be inherent to individuals and the second would be classified into two categories: self-dignity and dignity in a relationship. The former refers to dignity in relation to oneself; and the second, to dignity in the interactions of an individual with other individuals and in society, this being the context of the promoter/violator elements of dignity (Table 1).

\section{(Table 1)}

ELEMENTS OF PROMOTION AND VIOLATION OF DIGNITY

\begin{tabular}{|c|c|c|c|}
\hline \multicolumn{2}{|c|}{ PROMOTION OF DIGNITY } & \multicolumn{2}{|c|}{ VIOLATION OF DIGNITY } \\
\hline Estime, attention, courtesy & Respect & Disrespect & $\begin{array}{l}\text { Widespread disrespect } \\
\text { or disagreement }\end{array}$ \\
\hline Identification with the other & Empathy & To ignore & $\begin{array}{l}\text { Lack of consideration, attention } \\
\text { or care. }\end{array}$ \\
\hline Take charge of a situation & Control & Condescendence & $\begin{array}{l}\text { Give in to someone's feelings } \\
\text { or desires. }\end{array}$ \\
\hline $\begin{array}{l}\text { Increase capacities and } \\
\text { skills/autonomy }\end{array}$ & Empowerment & Indifference & $\begin{array}{l}\text { Make the individual feel smaller } \\
\text { or diminished }\end{array}$ \\
\hline $\begin{array}{l}\text { Encourage others in difficult } \\
\text { situations }\end{array}$ & Presence & Indifference & $\begin{array}{l}\text { Consider the individual invisible } \\
\text { or voiceless }\end{array}$ \\
\hline Be self-sufficient & Independence & Dependency & $\begin{array}{l}\text { Forcing depend on others } \\
\text { for basic needs. }\end{array}$ \\
\hline Dignity of others & Resistance & Contempt & $\begin{array}{l}\text { Treat someone in a way that } \\
\text { he has no value. }\end{array}$ \\
\hline $\begin{array}{l}\text { Recognize the humanity of } \\
\text { others, show appreciation }\end{array}$ & Recognition & Label & $\begin{array}{l}\text { Mark with connotation of moral } \\
\text { disability or social inferiority }\end{array}$ \\
\hline $\begin{array}{l}\text { Demonstrate common } \\
\text { respect }\end{array}$ & Courtesy & Defamation & $\begin{array}{l}\text { Making a person appear } \\
\text { threatening or dangerous }\end{array}$ \\
\hline $\begin{array}{l}\text { Minimize asymmetry } \\
\text { differences }\end{array}$ & Leveling & Objectification & $\begin{array}{l}\text { Treat someone as a thing, } \\
\text { not a person }\end{array}$ \\
\hline $\begin{array}{l}\text { Just survive in difficult } \\
\text { circumstances or "do your } \\
\text { best" }\end{array}$ & Perseverance & Discrimination & $\begin{array}{l}\text { Handle poorly based on status } \\
\text { reached }\end{array}$ \\
\hline $\begin{array}{l}\text { Praise, recognize value of } \\
\text { the other }\end{array}$ & Raise & Exploration & $\begin{array}{l}\text { Use or see someone just } \\
\text { as a means to an end. }\end{array}$ \\
\hline
\end{tabular}

(continue) 


\section{(Table 1 (Conclusion))}

ELEMENTS OF PROMOTION AND VIOLATION OF DIGNITY

\begin{tabular}{lc|cl}
\hline \multicolumn{1}{c|}{ PROMOTION OF DIGNITY } & \multicolumn{2}{c}{ VIOLATION OF DIGNITY } \\
\hline Strengthening Yourself & To encourage & Grouping & $\begin{array}{l}\text { See someone not as unique, but } \\
\text { only as a member of a collective. }\end{array}$ \\
\hline Rising for the oppressed. & Defend & Revulsion & $\begin{array}{l}\text { Treat the other as if it were } \\
\text { disgusting or contaminated }\end{array}$ \\
\hline $\begin{array}{l}\text { Strengthening oneself, } \\
\text { against violations of dignity }\end{array}$ & Preparation & Suspicious & $\begin{array}{l}\text { Distrust / treatment to someone } \\
\text { as committing bad deeds. }\end{array}$ \\
\hline Do not judge difference. & Acceptance & Exclusion & Make someone feel unwanted \\
\hline Honor and cherish others. & Love & $\begin{array}{c}\text { Exclusion or } \\
\text { Bullying }\end{array}$ & $\begin{array}{l}\text { Threatening or intimidating na } \\
\text { individual }\end{array}$ \\
\hline
\end{tabular}

Source: Elaborated by authors based on Jacobson, 2009.

It is from this relational perspective that this work was discussed, since the promotion and violation elements of dignity are based on the relationship and coexistence in the organizational environment.

\subsection{Diversity and "Inclusion" of PwD within Organizations}

Law 8,213/91 was a watershed in the lives of the PwD, since it formally recognizes their right to be "included" within work organizations, since they were historically placed at the margins of employability (Snell \& Bohlander, 2015), support, and labor rights, with a negative impact on their self esteem (Lima, 2012).

While acknowledging the social progress with this law, it should at least be suspected that it, in itself, is not capable of guaranteeing that the PwD are treated fairly, that they feel included, that they have equal opportunities and are represented in all functions and organizational levels, aspects that have the meaning of an effective inclusion (Torres \& Pérez-Nebra, 2014).

The issue of the inclusion of $\mathrm{PwD}$ within the organizational-labor context is also discussed in the field of cultural diversity in organizations. In this direction, one can understand diversity as the representation of people with different group identities in a given social system (Cox, 1994); as varied perspectives that the members of different identity groups integrate in the scope of work (Thomas \& Ely, 1996); or yet, a mixture of people with different group identities within the same social system (Nkomo \& Cox, 1999). 
Diversity would have at least two dimensions, the primary and the secondary, the first being geared towards biologically determined characteristics, and the second, characteristics that the person can modify consciously and deliberately (Hanashiro, 2008). For Torres and Pérez-Nebra (2014), there would be the category of skills and values (cognitive) and a more stable and difficult category to be modified (demographic).

By inclusion, the idea of accepting people is assumed, linked to a feeling of being welcomed and valued as a member of a given organization, at its various levels (Hayes, 2002). For Torres and Pérez-Nebra (2014), the experience of inclusion as a perception of individuals regarding their acceptance, respect and appreciation, in view of their group and individual identity, consists of the person actually feeling included.

In this direction, the experience of inclusion depends on an inclusive behavior, this being "the individual and group actions resulting or provoking organizational policies and procedures that promote an inclusive climate and are adopted by the individual, the members of the work group and the organization" (Torres \& Pérez-Nebra, 2014, p. 530).

Several studies aimed at the inclusion of PwD portray the difficulties that they face, such as: characteristics of the work environments, contracting and hosting of the PwD (Gilbride et al., 2003); accessibility in leisure, work and education (Sassaki, 2009); deafness and prejudice (Witkoski, 2011); the importance of work for people with disabilities (Ragazzi, 2010); diversity policy and labor relations (Irigaray \& Vergara, 2011); public policies and organizational practices in the insertion of the deaf (Irigaray \& Viana, 2012); fundamental right to social inclusion (Lima, 2012); the meaning of work for PwD (Lima et al., 2013).

Thompson (2010, apud Torres \& Pérez-Nebra, 2014), on the other hand, analyzed the difficulties that recruiting and selection professionals often face with government programs and a certain lack of interest in working from some groups of PwD.

In general, what is noticeable in most studies is the need to raise awareness in dealing with issues relevant to the $\mathrm{PwD}$, in various instances, in order to allow the effective inclusion of these people within organizations. In the case of the deaf, in particular, listeners may not know how to approach, how to treat or behave in front of them, because the contact may cause strangeness from the very beginning, which will depend on the quality of the interaction developed among all in the relationship (Ragazzi, 2010; Silva, 2006).

This kind of attitude and behavior of strangeness towards the other can be derived from stereotyping, prejudice and discrimination. By stereotype, 
we mean a characterization of people, but without judgment, while prejudice is an evaluative/judgmental attitude about this characterization and discrimination is an act/behavior linked to prejudice (Torres \& Pérez-Nebra, 2014).

In paradigmatic terms of the studies on diversity and inclusion, Torres and Pérez-Nebra (2014), quoting Thomas and Ely (1996), suggest three positions: 1 . discrimination and justice; 2 . access and legitimacy; and 3. learning and effectiveness. The first presupposes that "we are all equal" or "we wish to be all equal," with assimilation being the central idea. The second is based on the idea of acceptance of differences, with differentiation as idea-force. The third is represented by the idea of integration/inclusion, whose focus would be on the admission of a single team with their differences.

All of these diversity-inclusion issues in organizations evoke the need for the idea of inclusive management of diversity (Hanashiro, 2008). In fact, it would be with the ongoing diversity management that a culture of inclusion could be developed, which would lead to the reinforcement of diversity itself, through the implementation of a contracting and promotion system (Torres \& Pérez-Nebra, 2014).

However, there is a feeling of devaluation in organizations, which involves $\mathrm{PwD}$, possibly because they feel excluded, even though they are inserted. This question, it is suggested, would be due to the varied forms of violation of dignity in relationships (Jacobson, 2009). It is thought that from the various experiences of the violation of dignity in the relationship, a process of social isolation of the PwD can result (Cacioppo et al., 2008; Devine et al., 2015), with all the risks that this phenomenon can bring to the psychological and physical integrity of people (Cacioppo \& Cacioppo, 2013).

For Devine et al. (2015), social isolation would be a more objective concept than solitude, comprising a continuum ranging from the absence of contact with other people, to high levels of social contact or participation. According to Cacioppo and Cacioppo (2013), physical isolation can contribute to loneliness, this being a pain that someone feels when the need for connection is not met, the fact of being able to be felt anywhere, even when surrounded by family and friends.

Cacioppo et al.(2008) suggest that the quality of our social relationships, not quantity, is what would be an essential part of what is needed to be healthy and happy. In this sense, in order to establish better social relations within organizations, it is assumed that actions that promote dignity should be more frequent than those that violate.

Taking the deaf as a focal point, the impression one may have is that having some limitation would make them incapable of assuming and exer- 
cising some functions within the company (Irigaray \& Vergara, 2011). In view of this, it remains for them to submit to and assume the social space determined by law, which is generally static and bounded by the glass ceiling effect (Idem).

In any case, it is thought that this insertion of the deaf, more than a de facto inclusion, can trigger a process of social isolation, which, as we all know, can have serious negative consequences for a healthy and happy life. Thus, if we know that loneliness is a risk factor for poor health and well-being, the next question is what can we do to mitigate it? (Cacciopo \& Cacciopo, 2013, p. 42).

\subsection{Deaf people and their communication - eyes that hear and hands that break silence}

It is known that one of the faculties of the human being is language (Aristotle, 1985). Language, in the strict sense, can mean "the faculty of speaking (speaking in power) or the totality of human languages" (Comte-Sponville, 2003, p. 352). According to Chanlat and Bédard (1996, p. 127), "man is, before all, a loquens homo; It is through language that he constructs his world, and space is, above all, a universe of words."

Language makes real thinking through speech, which is why man communicates and maintains his active interaction with his peers and the environment in which he lives (Leal, 2007).Thus, speech "is for the constitution of the individual just as language is for the definition of the human species, for it is through it and its vicissitudes that personal existence is constructed" (Chanlat \& Bédard, 1996, p. 128).

In other words, speech would be the "creation of a discourse by the updating of language (as a faculty) through a language (as a conventional and historical system)" (Comte-Sponville 2003, p. 236). Language can be understood as that which is "what we are talking about: it is a set of conventional signs, articulated [...] and submitted to a certain number of structures [...]" (Idem).

One can think of the use of speech in the construction of the self and the other, since "every time a person makes use of the word, he tries to express and communicate an image of himself [...]" (Chanlat \& Bédard, 1996, p. 131). This might suggest that "when the other is not interested in us, then he/she would not be interested in the expression and communication of ourselves," and probably "we would not be interested in the other, by means of his/her expression and communication." 
In addition, it is alleged that "when a speaker is in the same condition as all the other members of the group, there one can find a norm, on the basis of which one can evaluate their characteristics of individual expression" (Chanlat \& Bédard, 1996, p. 131). Faced with this, one should take into account the limitation "that the language in which we express ourselves has an implication on the kind of reality we learn.[...] the particular language of which we serve bears its own limits ..."(Idem). Similar to the "Inuit Eskimo language in which the notion of snow contains a variety of words [...]" (Idem), it can be considered that, for the deaf, speaking in a "particular" language, there can be different meanings for a certain signifier.

Thus, communication would not only be possible to occur through verbal speech, since deaf people generally communicate without using verbalized words, using a peculiar and structured language, which in Brazil is called Libras - Língua Brasileira de Sinais or Brazilian Sign Language (Segala $\&$ Kojima, 2012). Libras is considered the mother tongue of the deaf (Law $10,436,2002)$. The hands take the place of pronounced words and make the abstract concrete, that is, give "body" to the thought. The eyes hear what the hands say, they break the silence.

Sign language uses hands, arms, eyes and makes use of facial expressions, which are intonation mechanisms. Facial and/or body expressions are responsible for expressing emotion, transmitting attitudes, and communicating personality traits, so that they are central to nonverbal communication (Segala \& Kojima, 2012). In the view of oralists, the deaf person who only communicates with his/her hands is one who is classified in a subgroup outside the capacity of the oralized, and is one who will approach the listener as having a "sign of superiority" (Witkoski, 2011).

Among the barriers encountered by deaf people, possibly the most relevant is communication. Thus, aware of some of these difficulties, in order to meet the demand of the deaf to realize their communication with the listeners, the federal government approved Law 12,319/10, which regulates the exercise of interpreters of Libras. Therefore, public institutions and/or private organizations now have the obligation to maintain an interpreter to attend to deaf citizens and ensure their right to communication (Decree no. 5,626/05).This legal provision, we recognize, signals a worthy act in relation to the deaf, however, meritorious as the law may seem, it still may not be enough to effect a process of inclusion and dignity in organizations.

It is known that the process of cultural adjustment in a foreign culture involves the question of language (Kelman, 2010). If this seems to be the case, the deaf who dominate the Portuguese language may adapt more easily, 
and their "inclusion" process be less painful. However, it is believed that there can be a more democratic perspective, that of an intercultural adaptation, in which the deaf and listeners recognize each other and are willing to adapt to a mutual cultural enrichment in a given cultural space (Machado \& Teixeira, 2015, 2015a). After all, when practicing the difference between languages, the work of translation inevitably makes their similarities evident (Ottoni, 2005).

\section{METHOD}

In order to meet the objective of the research, a qualitative approach, of a descriptive nature was adopted to specify important traits, and dimensions of a phenomenon (Sampieri, Collado, \& Lucio, 2013), as well as an interpretative approach, as it uses subjectivity as an instrument of understanding, constructivist, a constant "coming to be". The purpose of qualitative research is to explore not only opinions or experiences, but what they represent for each respondent (Bauer \& Gaskell, 2002).

The research was conducted by means of conversational interviews (Yin, 2016) with 13 deaf people (9 men and 4 women - denominated S1 .... S13), between oralized and unoralized persons, inserted within organizations or with prior work experience, who communicated in Libras. The average age of the group was 32 years, with 7 years of work experience on average. The subjects' schooling corresponds to: secondary education (7), completed higher education (4), higher education in course (2). None of the respondents held managerial positions.

The data collection was done by means of an interview with a predetermined agenda, which allows the previous elaboration of a script of questions allowing for respondent interaction. According to Bauer and Gaskell (2002), this type of interview should not be based on questions and answers, but rather on a guiding topic that leads the researcher to "invite" the respondent to speak at length. The agenda was previously elaborated, following the proposal of Jacobson's study (2009), based on the elements of promotion and violation of dignity, from the perspective of two facets: self-dignity and social dignity.

Because the subjects were deaf, the support of an interpreter was required, since the investigators did not have full domain of Libras. Interaction with the interpreters was fundamental, although some if the deaf people were oralized and could read lips. 
One way for data collection that was not previously planned was by means of the WhatsApp technology which allowed for various actions during the interviews such as: conversation with the subject; appointment scheduling; appointment of new respondents; further information on customs / deaf culture and the learning of some signs.

The interviews were videotaped, being another source that contributed to the analysis and interpretation of the results, as well as recorded in audio (translation of the interpreters), transcribed in its entirety, and later read and submitted to five analytical phases, according to the script proposed by Yin (2016): 1. Compilation/Classification; 2. Decomposition; 3. Recomposition/arrangement; 4. Interpretation; and 5. Conclusion.

\section{INTERPRETATION AND DISCUSSION OF RESULTS}

From the extensive readings and in-depth re-readings of interview transcripts, some elements that promote and violate dignity emerged in the light of Jacobson's theory (2009).

In a first approximation, it was noticed that the subjects had a good understanding that relationships are essential to the inclusion of the PwD, which would be the responsibility of all those involved. What should be expected, then, is the establishment of good-quality relationships through which the deaf perceive their acceptance, respect and appreciation, given their group and individual identity (Torres \& Pérez-Nebra, 2014). It could also be said that the ideal would be for relations to be based on decent action (Machado \& Teixeira, 2016; Teixeira, 2008).

It was noted that the promotion of dignity is felt and perceived by the deaf within situations of solidarity, or in the "helping of others", in living together, in the dealings that involved teamwork, according to the representative talk of S3: "[...] Many people helped me, and I felt important [...]". In general, the research subjects declared that "the help of the other" to learn the job and, consequently, to perform their professional role well, was especially important to them. This suggests that good quality relationships have the potential for creating the meaning of team or team spirit, as well as the generation of a learning-friendly environment, which approximates the perspectives of empowerment and respect (Jacobson, 2009).

Some subjects made it clear that respect for the deaf generates safety and well-being. S3, for example, feels himself important due to the help received from everyone, provoking a sense of belonging, which is felt by 
all the respondents when well received by listeners and accepted in their deafness. The extract of all this composite of good interaction may result in elevated self-esteem (Lima, 2012) and in "self-empowerment" (Jacobson, 2009). With regard to the potential for learning, the establishment of productive relationships, in these cases, tended to favor non-social isolation, reducing the risk of developing cognitive difficulties, among others.

Not only the relationship with co-workers is relevant to the deaf, a good relationship with the boss is important for them to feel like part of the whole, as S6 states when referring to the "help from the boss". The boss's support is usually essential in the process of feeling ownership, recognition, as well as a "sign of appreciation" and potential growth in the organization. In this last aspect, in particular, the correct conduct of hierarchical superiors is probably not enough, since it is necessary to define specific organizational policies that aim to promote the inclusive management of diversity and to avoid the glass ceiling effects (Hanashiro, 2008; Irigaray \& Vergara, 2011; Torres \& Pérez-Nebra, 2014).

This insertion within the organization, it may be recognized, may have brought expectations of growth, of valorization to the deaf. i.e. a certain sense of "being equal to the listener", a potential for elevated self-esteem. However, it seems that the fact of "being equal" may be based on the assumptions of "discrimination and justice", so that it does not escape the limitation of the desire "we want to be all the same" (Torres \& Pérez-Nebra, 2014).

On the other hand, in their organizational experiences, several subjects reported flagrantly negative experiences. The contempt for being deficient and the devaluation for being "different" caused segregation imposed by some listeners. The presence of prejudice and discrimination in relation to the deaf can be considered a fact in the experiences of the majority of the research subjects.

In addition, the experiences of contempt and segregation reported certainly do not contribute to the inclusion of the PwD within organizations. On the contrary, they hinder or even make it impossible to happen. Here are some representative sections of the social isolation imposed on the deaf by listeners:

[...] this relationship issue is more difficult (to respond to\}, because I have only come in recently, I am a little separated, I am left alone, because I cannot communicate with people. I feel that I need a lot of help, to feel safe, and I still have not developed that level of relationship. (S3) 
From this speech and from others, one can apprehend several aspects that corroborate the social pain suffered by the respondents. In S3's speech, one notices a certain "blame of self" for having "entered now" and/or being "somewhat separated", because according to her, she is alone because "she cannot communicate with people."

What is perceived in this study is that sometimes, in addition to the lack of diversity and inclusion policies, along with a culture of inclusion and consequent inclusive behaviors, there may still be a certain "convenience" in allowing the deaf to blame themselves for "not being able to communicate".

In S3's speech, other aspects have occurred, that somehow are linked with elements of violation of dignity, such as ignorance, indifference, contempt, discrimination, repulsion, exclusion (Jacobson, 2009).These experiences of violation of social dignity in the relationship seem to be related to a process of social isolation, which, as we know, can pose serious risks to a person's physical and mental health (Cacioppo \& Cacioppo, 2013), so it should be something to be avoided.

When feeling disrespected as a person and treated as a "thing", a certain objectification element is created of the PwD (Jacobson, 2009). An organization that allows itself to treat its internal stakeholders this way definitely behaves in a manner against a Dignified Organizational Action (Teixeira, 2008).

Silva (2006) lists prejudice as a defense mechanism for something that poses a threat, a risk of imminent social denial, assuming that the relation or approach to the deaf by someone may involve into a threat of his rejection by society. The role of stigmatization (Torres \& Pérez-Nebra, 2014) of PwD, and of those that relate to them, incentivizes the process of the marginal inclusion of the deaf (Lima, 2012).

In the case of the deaf, it does not seem that the stigma has diminished because they are inserted within an organization, not even if acceptance and respect have increased within the organization, since what seems to exist is a tolerance on the part of colleagues and managers only as a result of legal impositions (Irigaray \& Vergara, 2011).

The study recognized the fact that the deaf seem to be victims of discrimination in the organization, which may be evidenced even in the hiring process, since according to S2 "the company recruits the deaf to work anywhere. [...] I think the company only hires the deaf because of the law. They do not respect people". The way in which a good part of the contracting takes place in organizations does not promote the dignity of the deaf, on the contrary, it could be considered as an "exploration" (Jacobson, 2009). 
S1 declares that "the company does not give the handicapped an opportunity". S7 states that the "company does not value" the deaf, since they remain in the same positions for long periods of time. This fact suggests that deaf people are not normally considered targets of opportunities for career development, which effectively does not contribute to the inclusion in the organization.

Although many deaf people are able to perform more demanding and competitive roles, they usually hold subordinate and low-paid positions (Ciszewski, 2005). S13 says: "I have a deaf colleague who was promoted, but this is not commonplace. It is very difficult to reach this level, to grow in the company." In practice, the deaf are often targeted for general services, cleaning, warehouse jobs or for areas with low chances of promotion. They are hostages of a glass ceiling effect (Irigaray \& Vergara, 2011; Torres \& Pérez-Nebra, 2014).

Communication is another prominent item for the inclusion of deaf people within organizations. Here, one perceives a conglomeration of manifested feelings, as: apprehension, nervousness, restlessness, anxiety, etc. S1 informs that, even when being oralized, communication continues to be a major impediment to working in the workplace. S3 says it is very difficult to communicate, and strives to learn everything they teach faster than the rest. Difficulties in communication are visible (Witkoski, 2011), generally more unfavorable to the deaf.

Kelman (2010) argues that the effort to master another language is critical for cross-cultural interaction. For Machado and Teixeira $(2015,2015 \mathrm{a})$, the ideal would be that a mutual recognition approach and a mutual cultural enrichment in the organization be created, which would transcend communication and contribute to improving the quality of relationships, essential to the health and happiness of workers (Cacioppo et al., 2008).

Still regarding communication, there were situations of harassment in the organization: "They called me a jackass, the same as the story of the monkey that does not hear" (S7), which generated indignation, discomfort and anger, and an outburst: "Why Call me that? I'm just like you, I work, I'm smart, I'm capable!”. S7 felt guilty for using signs/gestures, not voice. Through this and other experiences, you can see various elements of violation of dignity, disrespect, decreased other, contempt, labeling, objectification, exclusion, bullying (Jacobson, 2009).

Finally, it was perceived that prejudice and discrimination in the organization weakened inclusion, exposing the deaf to social isolation. 


\section{FINAL CONSIDERATIONS}

This paper reflected on how dignity is perceived by deaf people within organizations, their experiences in interactions with colleagues, bosses, and the organization itself. In addition, it sought to identify elements that promoted and violated their dignity in relationships.

The data captured suggest that the word "dignity" was not known by the subjects of the research. However, because of the dynamics of sign language, the deaf used other signals to designate what they wanted to understand. Therefore, the meanings of dignity attributed by the subjects were based on the notions of appreciation, respect and equality in relation to the listener.

During the "conviviality" with colleagues and bosses, however, the presence of the elements valorization, respect and equality, was not the rule. The experience of non-dignity in the relationship was present in the daily life of the deaf. There were few who indicated that the organization was concerned with "including them" in all courses, meetings etc.

From the point of view of the paradigms of diversity and inclusion, the subjects' reports were based on the presuppositions of the positioning "discrimination and justice".

Throughout the study, it was found that most of the subjects had extensive experiences with elements that violate their dignity, and only a few with promoting elements. It was also verified that the predominance of elements violating dignity generated a feeling of non-acceptance/inclusion, which almost always brought to the surface a feeling of isolation.

Thus, it may be inferred: the more intense the experience of the deaf with elements that promote dignity, the greater the individual's propensity to feel included, and the less risk of social isolation. Conversely, the more intense the experience with elements that violate dignity, the less the sense of inclusion is, and the greater the risk of social isolation.

In relation to the communicative/cultural difficulties of inclusion in organizations, the adoption of an organizational position aimed at reciprocal recognition and mutual cultural enrichment may be considered advisable. This approach could contribute to improving the quality of relationships within the organization, which is important for a healthy and happy life of all employees, not only the PwD.

It is believed that the inference and the recommendation proposed above bring new perspectives to the reflections on the behavior of individuals and organizational group interactions. In this sense, this article sought to contribute to organizational studies, based on a view of dignity within orga- 
nizations, linked to diversity/inclusion and risk of social isolation, focusing on the deaf.

As a suggestion for future research, it is understood that it would be pertinent and timely to search for more evidence to the proposed inference, as well as to deepen theoretical reflection on the possible relationships between dignity, diversity/inclusion and social isolation within organizations.

\section{DIGNIDADE PROMOVIDA OU VIOLADA: COMO A PESSOA SURDA INCLUÍDA A PERCEBE?}

\section{RESUMO}

Objetivo: Compreender como dignidade é percebida pelos surdos inseridos nas organizações, a partir de suas interações com colegas, chefes e a organização.

Originalidade/lacuna/relevância/implicações: No campo de estudos sobre dignidade organizacional, estuda-se o fenômeno sob diversos aspectos. No entanto, não foram encontradas pesquisas abordando a possível relação entre dignidade e inclusão nas organizações, tomando-se por foco pessoas surdas.

Principais aspectos metodológicos: trata-se de um estudo qualitativo realizado através de entrevistas com 13 funcionários surdos, entre oralizados e não oralizados, com experiência de trabalho em organizações na Região Metropolitana do Recife-PE, Brasil.

Síntese dos principais resultados: A maioria dos surdos se sentiam socialmente isolados, não contemplados pelas práticas de $\mathrm{RH}$, tampouco alvo de oportunidades nas organizações. A língua mostrou-se como a principal dificuldade à comunicação, embora apoiados por leis que visam garantir a quebra dessa barreira através de intérprete.

Principais considerações/conclusões: A visão de dignidade predominante, baseou-se nos elementos valorização/respeito/igualdade. Infere-se que quanto mais intensa for a experiência com elementos violadores da dignidade, menor será o sentimento de inclusão ou maior o sentimento de não aceitação, portanto, maior o risco de isolamento social dos surdos. Acreditase que, entre outros aspectos, uma postura organizacional voltada ao reconhecimento recíproco e enriquecimento cultural mútuo, contribua à melhoria da qualidade das relações entre surdos e ouvintes. 


\section{PALAVRAS-CHAVE}

Dignidade. Surdos. Organização. Inclusão. Isolamento social.

\section{DIGNIDAD PROMOVIDA O VIOLADA: ¿CÓMO LO PERCIBE LA PERSONA SORDA?}

\section{RESUMEN}

Objetivo: Compreender como los sordos que se encuentran en las organizaciones, perciben su dignidad, a partir de suas interacciones con los companeros, jefes y la organización.

Originalidad/laguna/relevancia/implicaciones: En el campo de estudios sobre dignidad organizacional, se estudia el fenómeno sobre varios aspectos. Entretanto, no han sido encontradas investigaciones que traten la posible relación entre dignidad e inclusión en las organizaciones, enfocando personas sordas.

Principales aspectos metodológicos: Se trata de um estudio cualitativo realizado a través de entrevistas com 13 funcionários sordos, entre oralizados e no oralizados, con experiencia de trabajo em organizaciones en la Region Metropolitana de Recife-PE, Brasil.

Síntesis de los principales resultados: La mayoria de los sordos se sentian socialmente aislados, no contemplados por las prácticas de $\mathrm{RH}$, tampoco somente que las oportunidades en las organizaciones. La lengua se ha mostrado como la principal dificultad a la comunicación, aunque esten apoyados por leyes que les garantizan el derecho a un intérprete para evitar essa barrera.

Principales consideraciones/conclusiones: La visión de dignidad que predomina, se ha baseado en los elementos valorización/respeto/igualdad. Se concluye que cuanto mas intensa sea la experencia con elementos violadores de la dignidad, menor será el sentimento de inclusión o mayor el sentimento de no aceptación por lo tanto, mayor el riezgo de aislamiento social de los sordos. Se cree que, entre otros aspectos, una postura organizacional que se reconozca reciprocamente, en un reconocimiento cultural mútuo, que contribuya a una mejor calidad em las relaciones entre sordos y oyentes. 


\section{PALAVRAS-CLAVE}

Dignidad. Sordos. Organización. Inclusión. Aislamiento social.

\section{REFERENCES}

Abbagnano, N. (1998). Dicionário de filosofia. São Paulo: Martins Fontes. Aquinas, T. (2011). Summa Theologica. (p. 1265-1274). Complete \& Unabridged American Edition Translated by Fathers of the English Domician Providence. Kindle Edition.

Aquino, T. (2008). O ente e a essência [Opúsculo] (M. S. Carvalho, Trad.). LusoSofia Press, Corvilhã.

Aristóteles. (1985). A Política (M. G. Kury, Trad.). Brasília: UnB.

Baker, H. (1961). The image of man. New York: Harper \& Brothers.

Bauer, M. W., \& Gaskell, G. (2002). Pesquisa Qualitativa com texto, imagem e som: um manual prático (P. A. Guareschi, Trad.). Petrópolis: Vozes.

Cacioppo, J. T., Hawkley, L. C., Kalil, A., Hughes, M. E., Waite, L. J., Thisted, R. A. et al. (2008). Happiness and the invisible threads of social connection: The Chicago Health, Aging, and Social Relations Study. In M. Eid \& R. Larson. The Science of Well-Being. (p. 195-219). New York: Guilford.

Cacioppo, J. T., \& Cacioppo, S. (2013). Social isolation. XXXIV Interamerican Congress of Psychology - Knowledge, Diversity and Integration, Brasília - DF. Chanlat, A., \& Bédard, R. (1996). Palavras: a ferramenta do executivo. In J. F. Chanlat (Coord.). O indivíduo na organização: dimensões esquecidas. (v. I). (p. 125-148). São Paulo: Atlas.

Ciszewski, A. C. V. (2005). O trabalho da pessoa portadora de deficiência. São Paulo: LTr.

Comte-Sponville, A. (2003). Dicionário filosófico. São Paulo: Martins Fontes. Constituição da República Federativa do Brasil de 1988 (1988). Brasília, DF. Cox, T. (1994). Cultural diversity in organizations: theory, research and practice. San Francisco: Berret-Koehler.

Crowley, M. (2013). Gender, the labor process and dignity at work. Social Forces, 91(4), 1209-1238. DOI: https://doi.org/10.1093/sf/sot042. 
Decreto n. 5.626, de 22 de dezembro de 2005 (2005). Regulamenta a Lei no. 10.436, de 24 de abril de 2002, que dispõe sobre a Língua Brasileira de Sinais - Libras, e o art. 18 da Lei no 10.098, de 19 de dezembro de 2000. Brasilia, DF. http://www.planalto.gov.br/ccivil_03/_ato2004-2006/2005/ decreto/d5626.htm.

Devine, P., Johnston, F., Anand, J. C., Montgomery, L., Dhónaill, C. N., \& O'Hagan, L. (2015). Social isolation and older man - meeting the need? Knowledge Exchange Seminar Series - KESS, Dublin.

Gilbrid, D., Stensrud, R., Vandergoot, D., \& Golden, K. (2003). Identification of the characteristics of work environments and employers open to hiring and accommodation people with disabilities. Rehabilitation Counseling Bulletin, 46(3), 130-138.

Gosdal, T. C. (2007). Dignidade do trabalhador: um conceito construído sob o paradigma do trabalho decente e da honra. São Paulo: LTr.

Habermas, J. (2010). Teoria de la acción comunicativa: racionalidade de la cción y racionalización social. Madri: Taurus.

Hall, J. P., Shartzer, A., Kurth, N. K., \& Thomas, K. C. (2017). Effect of medicaid expansion on workforce participation for People with Disabilities. American Journal of Public Health, 107(2), 262-264. DOI: 10.2105/ AJPH.2016.303543.

Hanashiro, D. M. M. (2008). Convivendo com a diversidade cultural. In D. M. M. Hanashiro, M. L. M. Teixeira \& L. M. Zaccarelli (Orgs.). Gestão do fator humano: uma visão baseada em stakeholders (2nd ed.). (p. 45-76), São Paulo: Saraiva.

Hayes, B. C. (2002). Creating inclusive organizations: its meaning and measurement. Dissertation (PhD in Philosophy), Old Dominion University, Norfolk.

Hodson, R., \& Roscigno, V. J. (2004). Organizational success and worker dignity: complementary or contradictory? American Journal of Sociology, 110(3), 672-708. DOI: 10.1086/422626.

Instituto Brasileiro de Geografia e Estatística - IBGE. (2010). Censo demográfico de 2010. Retreived April 25, 2016, from http://www.ibge.gov.br/home/ estatistica/populacao/censo2010/.

Irigaray, H. A. R., \& Vergara, S. C. (2011). O tempo como dimensão de pesquisa sobre uma política de diversidade e relações no trabalho. Cadernos EBAPE.BR, 9(4), 1085-1098. Retreived April 25, 2016, from http://bibliotecadigital.fgv.br/ojs/index.php/cadernosebape/article/view/5235/3969.

Irigaray, H. A. R., \& Viana, A. (2012). A inserção dos surdos no mercado de trabalho: políticas públicas, práticas. XXXVI Encontro da Associação Nacional de Pós-Graduação e Pesquisa em Administração - EnANPAD, Rio de Janeiro, RJ. 
Jacobson, N. (2007). Dignity and health: a review. Social Science \& Medicine, 64, 292-302. DOI: 10.1016/j.socscimed.2006.08.039.

Jacobson, N. (2009). A taxonomy of dignity: a grounded theory study. Social Science \& Medicine, 64, 292-307. DOI: 10.1186/1472-698X-9-3.

Kant, I. (2005). Fundamentação da metafísica dos costumes e outros escritos. São Paulo: Martins Claret.

Kelman, C. A. (2010). Multiculturalismo e surdez: uma questão de respeito às culturas minoritárias. In Fernandes, E. (Org.). Surdez e bilinguismo (3rd ed.) (p. 87-103). Porto Alegre: Mediação.

Koehn, D., \& Leung, A. (2008). Dignity in Western versus in Chinese Culture: theoretical overview and practical illustrations. Business \& Society Review, 113(4), 477-504. DOI: 10.1111/j.1467-8594.2008.00329.x.

Leal, M. M. Aplicação dos princípios da dignidade da pessoa humana e boa-fé nas relações de trabalho - as interfaces entre a tutela geral das relações de trabalho e os direitos subjetivos individuais dos trabalhadores. Revista Jurídica, 8(82), 84-99. Retreived April 25, 2016, from http://www.planalto. gov.br/CCIVIL_03/revista/Rev_82/Artigos/PDF/Larissa_rev82.pdf.

Lei no. 8,213, de 24 de julho de 1991 (1991). Dispõe sobre os Planos de Benefícios da Previdência Social e dá outras providências. Seção VI, Dos Serviços. Subseção II, Da Habilitação e da Reabilitação Profissional. Artigo 93. Brasília, DF. Retreived April 25, 2016, from http://www.planalto.gov.br/ CCIVIL_03/leis/L8213cons.htm.

Lei no. 10.436, de 24 de abril de 2002 (2002). Dispõe sobre a Língua Brasileira de Sinais - Libras. Brasília, DF. Retreived April 25, 2016, from http:// www.planalto.gov.br/ccivil_03/leis/2002/110436.htm.

Lei no. 12.319, de 1 de setembro de 2010 (2010). Regulamenta a profissão de Tradutor e Intérprete da Língua Brasileira de Sinais - LIBRAS. Brasília, DF. Retreived April 25, 2016, from http://www.planalto.gov.br/ccivil_03/_ Ato2007-2010/2010/Lei/L12319.htm.

Lima, J. N. (2012). Direito Fundamental à inclusão social: eficácia prestacional nas relações privadas. Curitiba: Juruá.

Lima, M. P., Tavares, N. V., Brito, M. J., \& Cappelle, M. C. A. (2013). O sentido do trabalho para pessoas com deficiência. Revista de Administração Mackenzie, 14(2), 42-68. Retreived April 25, 2016, from http://www.scielo. br/scielo.php?pid=S1678-69712013000200003\&script=sci_arttext.

Margolis, J. D. (1997). Dignity in the balance: philosophical and practical dimensions of promoting ethics in organizations. (PhD thesis), Harvard University, Cambridge. 
Machado, M. M., \& Teixeira, M. L. M. (2015). Adaptação cultural ou adaptação intercultural na expatriação. XXXIX Encontro da ANPAD - EnANPAD, Belo Horizonte, MG.

Machado, M. M., \& Teixeira, M. L. M. (2015a). Adaptação intercultural na expatriação: em busca de um conceito. III Congresso Brasileiro de Estudos Organizacionais - CBEO, UFES - Vitória, ES.

Machado, M. M., \& Teixeira, M. L. M. (2016). Dignidade nas organizações: um olhar para além do moderno. IX Encontro de Estudos Organizacionais da ANPAD - EnEO, Belo Horizonte, MG.

Medeiros, A. L. (2013). Cartografia simbólica da dignidade dos docentes de universidades brasileiras: uma reflexão à luz de Boaventura de Sousa Santos. Tese de Doutorado, Universidade Presbiteriana Mackenzie, São Paulo, SP. Retreived April 25, 2016, from http://tede.mackenzie.br/jspui/handle/tede/806.

Mignolo, W. (2013). Decolonialidade como caminho para a cooperação. Entrevista. Revista do Instituto Humanitas Unisinos - IHU On-line, 431(XIII). Retreived April 25, 2016, from http://www.ihuonline.unisinos.br/index. php?option $=$ com_content $\&$ view $=$ article $\& i d=5253 \&$ secao $=431$.

Mirandola, G. P. D. (1988). A dignidade do homem. São Paulo: GRD.

Nicolas, M. J. (2003). Introdução à Suma Teológica. In Suma Teológica (p. 1265-1274). (2nd ed.). São Paulo: Loyola.

Nkomo, S. M., \& Cox, T. (1999). Diversidade e identidade nas organizações. In S. R. Clegg, C. Hardy \& W. R. Nord (Eds.). Handbook de estudos organizacionais: modelos de análise e novas questóes em estudos organizacionais. (p. 334-360), São Paulo: Atlas.

Ottoni, P. (2005). Introdução: a prática da diferença. In P. Ottoni (Org.). Tradução: a prática da diferença (2nd ed.). (p. 9-174). Campinas, SP: Unicamp. Ragazzi, I. A. G. (2010). Inclusão social: a importância do trabalho da pessoa portadora de deficiência. São Paulo: LTr.

Rayman, P., \& Reynolds, J. (2001). Beyond the bottom line: the search for dignity at work. New York: Palgrave.

Riley, S. (2010). Human dignity: comparative and conceptual debates. International Journal of Law in Context, 6(2), 117-138. DOI: https://doi.org/10.1017/ S1744552310000030.

Sampieri, R. H., Collado, C. F., \& Lucio, M. P. B. (2013). Metodologia de Pesquisa (D. V. Moraes, Trad.). Porto Alegre: Penso. 
Santos, B. S., \& Nunes, J. A. (2010). Introdução: para ampliar o cânone do reconhecimento, da diferença e da igualdade. In B. S. Santos (Ed.). Reconhecer para libertar: os caminhos do cosmopolitismo multicultural (2nd ed.). (p. 25-68). Rio de Janeiro: Civilização Brasileira.

Sarlet, I. W. (2008). Dignidade da pessoa humana e os direitos fundamentais na Constituição Federal de 1988 (6th ed.). Porto Alegre: Livraria do Advogado.

Sassaki, R. K. (2009). Inclusão: acessibilidade no lazer, trabalho e educação. Revista Nacional de Reabilitação (Reação), ano XII, 10-16. Retreived 25 June, 2016, from https://acessibilidade.ufg.br/up/211/o/SASSAKI_-_Acessibilidade.pdf? 1473203319.

Sayer, A. (2007). Dignity at work: broadening the agenda. Organization, 14(4), 565-658.

Segala, S. R., \& Kojima, C. K. (2012). A imagem do pensamento: Libras - língua brasileira de sinais. São Paulo: Escola Educacional.

Shahinpoor, N., \& Matt, B. F. (2006). The power of one: dissent and organizational life. Journal of Business Ethics, 34(4), 663-683. DOI:10.1007/s10551006-9218-y.

Silva, L. M. (2006). O estranhamento causado pela deficiência: preconceito e experiência. Revista Brasileira de Educação, 11 (33), 424-561.

Snell, S., \& Bohlander, G. A. (2015). Administração de recursos humanos (16th ed). (M. L. G. L. Rosa, \& S. A. Visconti, Trad.). São Paulo: Cengage Learning. Stolarczyk, P. (2016). Equality of chances for people with disabilities in the labor market. Acta Sci. Pol., Oeconomia, 15(2), 139-149. DOI: 10.3233/ WOR-131641.

Teixeira, M. L. M. (2008). Dignidade organizacional: valores e relações com stakeholders. In M. L. M. Teixeira (Ed.). Valores humanos e gestão: novas perspectivas. (p. 81-94). São Paulo: Senac.

Teixeira, M. L. M., De Domenico, S. M. R., Dias, S. M. R. C., \& Mendes, L. H. L. (2014). Práticas de dignidade organizacional percebidas por trabalhadores na relação entre organização e stakeholders. XXXVIII Encontro da Associação Nacional de Pós-Graduação emAdministração - EnANPAD, Rio de Janeiro.

Teixeira, M. L. M., \& Bilsky, W. (2015). Faceting organizational theory. 15th Facet Theory Conference. Nova York, NY.

Teixeira, M. L. M. (2016). Organizational dignity theory: a proposal. XIX SemeAd - Seminários em Administração FEA-USP, São Paulo-SP.

Thomas, D. A., \& Ely, R. J. (1996). Making differences matter: a new paradigm for managing diversity. Harvard Business Review, 74(5), 79-90. 
Torres, C. V., \& Pérez-Nebra, R. (2014). Diversidade e inclusão nas organizações. In J. C. Zanelli, J. E. Borges-Andrade \& A. V. B. Bastos (Orgs.). Psicologia, organizações e trabalho no Brasil (2nd ed.). (p. 526-546). Porto Alegre: Artmed.

Witkoski, S. A. (2011). Educação de surdos e preconceito: bilinguismo na vitrine e bimodalismo precário no estoque. Tese de doutorado, Universidade Federal do Paraná, Curitiba.

Witkoski, S. A. (2015). Surdez e preconceito: a norma da fala e o mito da leitura da palavra falada. Revista Brasileira de Educação, 14(42), 565-606.

Yin, R. K. (2016). Pesquisa qualitativa do início ao fim (D. Bueno, Trad.). Porto Alegre: Penso. 